\title{
Relationship Marketing: An Important Tool For Success In The Marketplace
}

\author{
Hudson Nwakanma, (Email: hudson.nwakanma@famu.edu), Florida A \& M University \\ Annette Singleton Jackson, (Email: annette.singleton@earthlink.net), South Carolina State University \\ Janee N. Burkhalter, Georgia State University
}

\begin{abstract}
This paper looks at relationship marketing as an important tool for success in marketing. With product quality becoming a common standard in many industries, and no longer a major source of competitive advantage, many firms are scrambling to escape the mire of the 'commodity mentality' that has become part of most basic products in the market place today. Several of these firms are turning to relationship (RM) marketing as a means of differentiating themselves. This shift to RM is being fueled by fundamental cultural shifts, powerful databases, and a new focus on organizational structure; and is occurring more rapidly in some sectors and industries than others. Through the relationships they build, marketers turn data into knowledge by using the information, insight, and understanding gained over time and applying this information to mutual benefits with their customers. Many are realizing some of the advantages of relationship marketing which could be gained by both the marketer and the buyer. For the marketer, profitability, brand loyalty, product differentiation, and gaining competitive advantage are some major benefits of relationship building. For the buyer, the major benefits include: personalized attention from marketers, marketer's efforts to anticipate buyers' wants, and meaningful dialogues with the marketer. Trust, commitment, empathy, and responsiveness to customers needs are necessary ingredients for successful implementation of RM. Database technology, print-on-demand technology, and internal marketing are some of the tools available to marketers interested in taking advantage of an effective RM program. The jury is still out on how firms can successfully implement the RM program. Some firms have however, made successful attempts in implementing RM.
\end{abstract}

\section{INTRODUCTION}

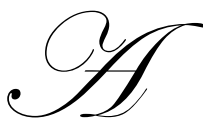

ccording to Boone and Kurtz (1998), "Marketing is the process of planning and executing the conception, pricing, promotion, and distribution of ideas, goods, services, organizations, and events to create and maintain relationships that will satisfy individual and organizational objectives." This definition highlights the difference between the traditional marketing that viewed marketing from a transactional point of view and the proper view of marketing as a process of building relationships between the seller and the buyer. Lasting relationships are built on the basis of mutual benefit and respect which means that any marketer that wishes to thrive in this ever increasing competitive market place must understand the concept of relationship marketing. A marketing philosophy that helps to explain why marketers should pursue relationship marketing is what Kotler called the marketing concept which that states that the best way to achieve an organization's objectives is through the satisfaction of its customers. To satisfy customers, it is not only necessary to know who they are, but what they need, and how to meet those needs in ways that are consistent with the organization's objectives.

Over the years, market segmentation has served as a major tool of implementing the Marketing concept in the market place. Market segmentation is the process of dividing customers with heterogeneous needs into groups that have similar needs. The concept of segmentation is derived from the principle of aggregation. The underlying assumption is that if you are able to identify a collection of individuals whose needs for a particular product are similar, then you may attempt to meet these similar needs with a single product and reach those individuals with a single communications strategy, a single distribution strategy and a single pricing strategy. Similarity from the point 
of view of market segmentation deals with approximation and not with precision of needs. The major disadvantage of this approach is that segmenting on the basis of similarity in many cases leads to group thinking. This means that marketers either consciously or subconsciously tend to fall back to the mode of classifying their customers as part of a group and not necessarily as individuals. This propensity to view customers as part of a group in many cases, encourages marketers to deal with individual customers from a transactional perspective, where each transaction is treated as a unique event. When the emphasis is on the group, those marketers who are able to convince their customers that their products are the closest to what they need tend to be the most successful. As Vavra (1995) put it, "Acquisition of and promotion of customers dominated, and customer service issues simply fell by the wayside." The emphasis was on creating or attracting as opposed to retaining customers. Fortunately, marketing is now being redefined as an increasing number of marketing professionals are beginning to realize the value of the "long-time client."

Traditional views of marketing are now being challenged and are slowly giving way to a new age of marketing, emphasizing the process of developing and maintaining an effective level of organizational-customer relationship. The "process" aspect of marketing is gaining prominence-having both transactional and relational qualities - which strives to establish, maintain, and enhance the relationship with customers in order to mutually satisfy the real objectives of both parties. "The customer is important," these new views say, "we want to retain our customers, not overlook them and have them defect." Relationship marketing (RM) is the key to success under this new era of marketing.

Relationship marketing is the development of mutually beneficial long-term relationships between a seller and a buyer. From the firm's point of view, RM is the art of creating special personal ties with its customers. Customers on the other hand, view RM as an opportunity to share information about their needs and to have those needs fulfilled. The significance of relationship marketing is highlighted by the following statistics outlining the reasons why customers switch to competitors (Metupp.com 1999).

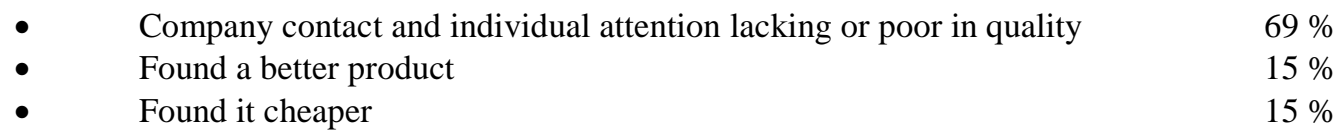

A variety of terms have been used to refer to relationship marketing. Some of these terms include: one-toone marketing, database marketing, micro marketing, relevance marketing, and interactive marketing. The formal acknowledgement of RM, in the authors' opinions represents a paradigm shift from the older, more traditional way of doing business. As adequately put by Buttle (1996), "in the 1950s, mass-marketing was key as market segmentation was in the 1970s. The 1990s however have ushered in an era of personalized marketing which includes highly focused strategies, increased market fragmentation, high levels of product quality, and more demanding customers."

The purpose of this paper therefore, is to discuss some of the major issues that may affect the successful implementation of a relationship marketing strategy. First, the paper will provide a more detailed definition of Relationship Marketing. Then some of the major benefits of and keys to success in implementing an effective RM strategy will be discussed. Finally, examples of current applications of RM in some organizations will be discussed.

\section{BACKGROUND}

Events in society often operate as the way life develops in the natural environment. For example, a butterfly in its early stages undergoes a joining and development of its male and female hereditary components resulting in a fertilized egg. Out of this egg develops the caterpillar, which is the insects' primary eating and growth stage. The next stage is the pupa when a "marvelous transformation" from caterpillar to butterfly takes place. Following the completion of this stage, a butterfly emerges, ready to court, mate and exchange hereditary information (as the cycle begins again). Just as a butterfly must grow and change, so must business entities and the fields of study which affect them. Accounting changes as often as various accounting boards issue statements and pass judgements. Economics is affected daily and must adapt to the changing society, and so must the field of marketing. Over the past five decades, marketing has seen a great deal of transformation. 
As indicated earlier, the 1950s produced mass marketing. The 1970s emphasized market segmentation. The1990s ushered in a new era of marketing that focuses more on the individual rather than groups. This practice of catering to the individual is not new. Originally, acquiring and retaining customers went hand-in-hand (Vavra 1995). Kania (1999) also alluded to this when she stated, "in the many years before the industrial Age, marketing was done by the local merchant...who knew everything about his or her customers." However, as marketing developed, acquisition and promotion became dominant while the retention and customer service received lip service at best.

The changing business environment, however, demands that a change take place. The number of customers is quickly reaching a plateau as the United States economy approaches its maturity stage. Population and Gross National Product growth are slowing down. Disposable personal income and median family income are leveling off. Deregulation and the increasingly complex marketplace are also calling for a change in marketing. Due to deregulation, market structure and competitive mannerisms have changed dramatically. Industries which have been deregulated are now open to competition, which means that marketers must work harder and firms must become customer, as opposed to transaction, focused (Vavra 1995). As regulation barriers have fallen, marketplaces in traditionally regulated industries have grown increasingly complex. The behavior of the airline industry over the last five years can provide a good example of some of the major challenges of deregulation. Several of the major airlines have declared bankruptcy and some well know airlines have disappeared from the marketplace altogether.

The consolidation of distribution channels has shifted the balance of power in favor of the channel and have created more distance between the marketer and the end consumer. The distance causes marketers to feel less responsible for consumers, thereby, leaving intermediaries to look after the customers-with mixed results. The resultant effect of this inadequate focus on customers, has led to many unsatisfied customers who are prime candidates for defection. Thus, leading to the constant effort to continuously acquire more customers. Additionally, the marketplace is graying as the society is composed of an increasing number of elderly people. Dual income households have become the order of the day. Education and other social factors, combined with consumers' skepticism regarding marketers' interest in satisfying their needs are creating a climate that demands major changes in the market place. Furthermore, intense and increasing global competition, increased market fragmentation, changing buying patterns, and customers who demand high quality products at reasonable prices and straight-talk from marketers have also contributed to the redefinition of marketing.

The traditional or transaction-focused view of marketing is being challenged because, (1) the short term focus of many marketing practices has failed to serve customers' best interests, and (2) corporate self-interest has not been served because, attraction is more expensive than retention (Buttle 1996). "Marketing is no longer simply about developing, selling, and delivering products. It is progressively more concerned with the development and maintenance of mutually satisfying long-term relationships with customers" (Buttle 1996).

\section{RELATIONSHIP MARKETING}

The definition of marketing has changed emphasis from purely transaction driven to being process driven. The process approach combines both transactional (related to fast-moving consumer goods) and relational (related to services) qualities, which strives to establish, maintain, and enhance mutually beneficial relationships with customers so as to satisfy the objectives of all parties. This new definition of marketing realizes the value of the lifetime customer and the importance of preventing customer defections. Customers are demanding more, therefore marketers must work to meet those demands. Marketers - just like the adult butterfly — must court their customers, build a relationship with them, and exchange vital information. Maintaining customers - as the new definition mentionsrequires the establishment of relationships that are characterized by trust, respect, and commitment. Marketers must be willing to discover and satisfy the needs of each customer as individuals. As appropriately put by John Naisbitt "A product for everyone is a product for no one in America today" (Vavra 1995).

Customer relationship building, which is a requirement of marketing's new era, is best fulfilled by one-toone, or relationship marketing (RM). Called "one of the hottest business trends going," Relationship Marketing is raising the curtain "on a new era of consumer privilege - an age of servile sales and service representatives who remember and anticipate a customer's every need" (Lardner). Relationship marketing places the customer at the 
center of all planning activity. The customer lets the firm know what is important and the firm responds accordingly (Patoka 2001). RM includes efforts to keep customers satisfied after purchase, taking steps to increase the likelihood of cross-purchasing, measuring the extent to which customers are satisfied, and translating the sales process into an effective program complete with two-way dialogue (Vavra 1995, Patoka 2001).

The goal of RM is to build long-term, trusting, "win-win" relationships which serve to maximize customer satisfaction and retention (Vavra 15). "Too many businesses try to be too many things to too many people," says Kenneth Cook, author of the American Marketing Association's Complete Guide to Small Business Marketing. "Get to know your customers intimately. Then you'll know what they are looking for" (White 1993). This strategy is one of the most effective and responsive for attaining competitive advantage and unique company differentiation in an increasingly competitive and changing environment. "It provides a much greater emphasis on informing and educating versus advertising, and keeping the customers you have as opposed to primarily focusing on capturing new customers." (Zinkewicz 1999)

Firms must provide excellent services, understand customers' expectations, adapt to challenges, provide additional services, offer value for dollars, advertise systematically, and invest in improvements in order to survive. As we enter into the new millennium, businesses must incorporate one-to-one marketing into their strategies in order to succeed. If relationship marketing has a big idea, it's embedded in the process of building profitable relationships with your customers. While traditional advertising is often based on that Eureka! sweaty-palm moment when the "big idea" is suddenly realized, relationship marketing follows a well defined process that places the customer at the very center of all thinking and activity. (Patoka 2000).

As correctly stated by Patoka (2000), "the trouble with "big idea" in relationship marketing, is that by its very nature, it's 'big'. And 'big' doesn't always translate when you get down to the little guy--your customer-- the person who has unique interests, needs, attitude, preferences, issues and opportunities, and of course, the authority to spend money on your offering." Where does the big idea fit into his world? He might notice it. Remember it for a while. Even go out and buy your product because of it. The 'big idea' is important for awareness and identity and all the other great things that mass media advertising does to support the brand. But it won't do much to change the relationship you have with your customer. To initiate and build a profitable relationship with your customer, you're going to have to get a lot closer. You might even have to adjust your "big idea" attitude (Patoka 2000). So how do you take the big idea and come up with a million little "big ideas", each tailored to the individual needs and interests of your customers? It has to do with strategy and ability to effectively implement one-to-one marketing. The emphasis is not on global, "big idea" thinking but relationship thinking. The question then is, what benefits can a firm derive from relationship marketing?

\section{Benefits Of Relationship Marketing}

From the Firms Point of view, relationship marketing can provide the following benefits:

1. Profitability: The longer the association between the company and its customer, the more profitable the relationship. From marketing experience, it has been established that retaining existing customers is more profitable than acquiring new ones. Relationship marketing provides a firm with an opportunity to participate in cross selling which increases overall sales volume and potential profit. Goodwill, which results in "word of mouth" promotion, helps to lower customer acquisition cost, and therefore impacts favorably on profit. According to Frederick Reichheld in his book, the Loyalty Effect, "a 5\% improvement in a company's customer attrition rate can push a company's profits up to $75 \%$ higher." This increased profit is a result of reduced acquisition costs, increased cross-selling, a high customer referral rate, decreased price sensitivity, and lower operating costs.

2. Brand loyalty: Brand loyalty is a benefit produced by an effective relationship marketing strategy. Relationship marketing encourages the customer to build a long- term relationship with a firm and its product. When this relationship results in consistent preferential treatment for a firm's product, the result is a brand loyal customer. A good example was a 2001 article in the USA Today which stated: "with their wings 
clipped by corporate travel cutbacks, thousands of business travelers may have to scramble this year to earn enough miles to retain their status among the nation's elite frequent fliers. Some are even paying thousands of dollars of their own money to earn enough miles to qualify for membership in the top tiers of frequenttraveler plans such as Continental Airlines' One Pass Platinum Elite and United Airlines' Mileage plus Premier Executive 1K." (USA Today June 2001). The fact that these travelers are willing to pay several thousand dollars to maintain their elite status is testimony to the nature of brand loyalty that can be created through relationship marketing.

3. Product Differentiation and Competitive Advantage: Closely related to Brand loyalty is the concept of product differentiation and competitive advantage. In this age of global competition, product differentiation, which leads to competitive advantage, is a must. Relationship marketing can provide an effective means of achieving both an effective product differentiation and competitive advantage. By placing a much greater emphasis on listening, marketers can more effectively determine what the customer wants and tailor the product to appropriately fit the customer's needs. This ability to better serve a customer can help a marketer to better differentiate his products and thus gain competitive advantage over those marketers that are not as responsive. Another source of both product differentiation and competitive advantage is in the area of marketing communications. When a marketer's communications strategy emphasizes providing the customer with information that will enable the customer educate him/her self instead of the traditional advertising and sales promotion, the customer is more likely to remain loyal to the marketer. This is completely opposite to always looking for ways to capture new customers, which of course, is very expensive.

From the customer's Point of view, relationship marketing can provide the following benefits

1. Relationship Marketing allows personalized marketing, which deals with direct one-to-one interactions between a marketer and its customers. One of the great benefits of interactive marketing is that buyers are in better positions to tell sellers what they want, and sellers can match their offerings to the needs of buyers. Nike uses its "Product Recommendation system" to help meet customer's needs. The prospective customer answers about a dozen questions about himself and how he'll use the shoes and the Product Recommendation System reveals which shoes are right for the customer. Armed with this information, the customer goes into his local shoe store to ask for shoes that are exactly right for him

2. Relationship Marketing allows a firm to anticipate customers' wants: marketers see a lot of customers with similar needs, tastes, and interests. They can use this experience, which is not available to individual customers, to anticipate what may appeal to an individual. This is particularly important because, a customer may have a general idea of what he or she wants, but the actual product design that matches his needs may not be immediately known to him. A good example is the BookMatcher system, which Amazon uses to perform what it calls the collaborative filtering function. Collaborative filtering works by collecting the likes and dislikes of many people on a collection of items (in this case, books). It then looks for books the other person has read and ranked highly which you haven't read and recommends them to you. In this case, relationship marketing allows an individual to gain exposure to a product that suits his individual needs that he would otherwise not have known existed.

3. Relationship marketing allows customers to receive relevant Information: An effective Relationship Marketing program provides customers with sufficient information to empower them to make correct purchase decisions. A very good example can be seen on the various on-line airline booking services. When a customer signs on with these on-line services and tries to book a flight, most of them provide the customers with a variety of choices that are in most cases sufficient to allow the traveler to make an appropriate travel plan. The most important thing about this system is that it allows the traveler instant comparative information which enables him to minimize transaction time, and in many cases maximize savings. 


\section{Characteristics Of A Successful Relationship Marketing Program}

There are several paths marketers may take to successfully implement a Relationship Marketing program. However, there are several attributes that must be present in order for a Relationship Marketing program to be successful. These include, trust, commitment, empathy, and responsiveness customers needs.

Trust is one the key elements for a successful RM program. Trust deals with the ability of the firm to implement a privacy policy that informs customers about what the firm plans to do with the personal data it is requesting from them (Kania 1999). In this era of identity theft, customers are very apprehensive of the ability of companies to protect their data. Thus a marker must devise a way of assuring the customer that her data is secure and that any information that the customer provides will actually be kept confidential. Trust represents customer confidence in a firm's reliability and integrity (Buttle 1996). Confidence, in turn, is associated with consistency, honesty, fairness, helpfulness, benevolence, and responsibility—all qualities any (successful) firm should exude. In addition to trust and confidence, commitment, concern, and respect are key elements as well. Commitment and trust encourage marketers to work at preserving relationships so customers will resist attractive short term alternatives and view potentially high risk actions as prudent. Additionally, customers must understand that this behavior will also promote efficiency, productivity, and effectiveness (Buttle 1996).

Commitment deals with a firm's desire to maintain a long-term relationship with its customer base. Without trust, commitment "flounders" (Buttle 1996). Concern, on the other hand, deals with marketer's appreciation and understanding of the need to continually strive for the welfare of their customers. The objective should always be to meet, if not exceed, customers' expectations. Respect includes affording customers the choice on how much personal information they wish to disclose and at the same time giving them something of value (Kania 1997)

Empathy from a Relationship Marketing point of view deals with an understanding of customers' expectations and is essential to success. If you do not understand your customers, you cannot serve them successfully. Customers must be understood, nurtured, and listened to. Alan Harari, President of Canada Direct, emphasized this when he stated, "If you're carrying on a dialogue with another person, you'll be much more interesting to that person if you listen and respond to what he or she has to say." This observation illustrates the importance of open and active two-way dialogue in Relationship Marketing. The appeal of RM lies in the fact that customers can express their desires and concerns and have them fulfilled or addressed. Relationship marketers must keep an open ear to their customer base and communicate openly and honestly with them.

Responsiveness in relationship marketing reflects an attitude of giving instead of getting. Firms put customers more at ease when the customer realizes that the marketer is as concerned with what benefits the customer is receiving as to the profit the firm is making. Additionally, open and free dialogue requires a communication pipeline through which a firm is alerted to issues and problems before they fester, and more timely and relevant messages can be delivered efficiently and effectively. Consistent active and open two-way dialogue, through which customer-centered, caring, and customer-oriented information is expressed, serves to build overall trust and confidence in a firm overall.

\section{TOOLS AVAILABLE FOR IMPLEMENTING RELATIONSHIP MARKETING}

The use of one-to-one media is essential to remaining competitive in today's globally competitive environment. According to Don Pepper and Martha Rogers in their book, the One-to-One future, there are three criteria for one-to-one media: "individually addressable, two-way, and inexpensive" (Kania and Allen 1999). Based on Pepper and Rogers criteria, the World Wide Web (the internet) is the perfect one-to-one medium.

The web allows marketers to capture customer knowledge in finite details by creating a relationship with each individual that visits a firm's Web site. Instead of simply talking at their customers, firms now have a way to conduct a two-way dialogue with its customers and can do so on an individual basis. Unfortunately, many firms with presence on the web have been using it as they used billboards or the television. Web presence is an important ingredient of success in relationship marketing, but if it is not coupled with a two-way dialogue, it will prove 
ineffective. In 2001, the Cluetrain Manifesto was published on the web by several people who felt that most corporate web sites talk "at" people instead of conversing with them (Allen.com, 2001). The Cluetrain Manifesto was very high on personalization.

According to Kania and Allen (1999), "Personalization allows marketers to gather information about each customer like never before possible with traditional marketing vehicles." Personalization helps to increase the likelihood that customers will return again and again to a firm's web site. "With the web, firms give customers the power, choice, and means to help the firm build a knowledge base. Relationship marketers no longer have to make guesses and assumptions" (Kania 1999). Personalization is a major player on the internet. It allows marketers to discover what is or is not working on the web site. It also allows marketers to gather valuable information for customer information files and to fulfill customer expectations. "A website that serves each customer individually [i.e.-is individually addressable] will be key to cementing a firm's relationship with a loyal customer base." (Kania and Allen 1999). "American Airlines---has a Web site that looks different to each of about a million registered American Advantage flyers. Logging on, [each customer is] greeted by name, and sometimes by a deftly directed offer." (Lardner 1999)

\section{Surveys}

Surveys, if done properly, can become an effective tool in one-to-one marketing by way of two-way dialog. Surveys allow the firm to collect personal information and opinions from its customers. However, firms must make sure to use/establish a two-way dialogue. Customers react poorly if scant attention is paid to their feedback. They will feel that their time and goodwill was wasted and may become weary of participating in future surveys.

\section{Database Technology}

Date base technology allows relationship marketers to "establish personalized dialogue with customers, resulting in more loyalty" (Dowling 1996). Database allows for the successful organization, management, and subsequent evaluation of customer information files. Firms serious about relationship marketing must use a database or campaign management application. Although campaign management systems have high price tags, "the cost of managing customer data is offset by money saved by not having to store certain items" and also makes it possible to bring personal service to every customer (Meckback 1998). Sophisticated customer databases, when used properly, allow for interactive, open dialogue and the creation of personal relationships with millions of customers at a time (Lardner 1999).

\section{Reorientation From Economies Of Scale To Economies Of Scope}

Traditionally, businesses pursued the policy of mass marketing which required serving several customers with the same product. Even when the emphasis shifted to market segmentation, firms adjusted their policy to finding the greatest number of people in a segment that had a need for a common product. The driving force behind this search for numbers was centered on the cost advantages that came with mass production. The concept of economies of scale prescribes volume production as a means of reducing per unit costs.

From their traditional points of view, mass production and economies of scale will not support an effective implementation of RM. Relationship Marketing requires the ability to serve the needs of each individual buyer from that individual's point of view. Mass production tends to serve the needs of groups. To effectively serve the needs of an individual, a firm must be flexible enough to tailor its manufacturing capability to produce a product that specifically meets the needs of each individual customer. This requires a shift from a mere emphasis on unit volumes to that of variety volume. This means that firms must be able to adjust their production facilities to produce variations of a product at high speed, with little or no down time. This concept, called economies of scope, is absolutely necessary for a successful Relationship Marketing program. 


\section{Print-On-Demand Technology}

In its most basic form, Print-on-Demand (POD) refers to digital-based printing systems that enable fast turnaround of high quality, low-cost, customized documents. POD documents in digital (disk/network) form can be easily manipulated, stored, retrieved, and ultimately printed in a run quantity of as little as one. Digital technology enhances the ease of content creation and drastically reduces make-ready costs, thereby allowing for the immediate turnaround of near off-set quality and totally customized documents in short-run quantities. According the IT in Publishing (June 7, 2000), "The arrival a decade ago of digital printing brought with it a new business model-print-ondemand technology or POD-which promised to liberate the publishing industry from the tyranny of long, inflexible print runs. Fixed costs could be reduced so drastically that books could be printed economically in hundreds or even dozens. Electronic date management would make it possible to implement "variable data" printing and produce individualized copies of any document." For example, traditionally, if a printer wanted to print promotions material using the traditional off-set printing method, he would be forced to print several thousands to be cost competitive. If these products are needed in say United States, Europe and Asia, the printer would print the materials in one location and ship them all over the world. The logistics and cost implications of this approach are mind boggling. However, with the POD system, all the printer does is digitally format the material and electronically distribute it to the three continents where they will be printed with little or no loss in time. This digital technology can also allow the printer to personalize the material to specific individuals at efficient rate.

\section{Internal Marketing}

For relationship marketing to flourish in an organization, in addition to understanding customer expectations, possessing a sophisticated customer database, designing a good website, and implementing surveys for information acquisition, the employees must be involved on a personal level. If employees believe in the cause, they will be willing to support the implementation of a successful program. Internal marketing is the key to success of any Relationship Marketing program. Employees play a major role in successful implementation due to the fact that they have the most and closest contact with customers. In fact, a firm's success is based on the interactions of employees with their customers - these are called "moments of truth"(Vavra 1999).

\section{Measurement Of Effective Relationship Marketing Programs}

To determine whether a program is effective requires some measurement. Several devices can be used to measure a firm's success in implementing a successful Relationship Marketing program. Scoring models rate a customer's likelihood of purchase based on a particular offer (Vavra 1995). Quality audits, on the other hand, continuously monitor a buyer's appraisal of quality, how the buyer determines quality, and what they consider to be key attributes of quality (Vavra 1995). Also, a firm serious about relationship marketing will measure their performance based not just on share of the market, but also on share of customer - the percentage of individual customer's annual or lifetime purchase. As stated earlier, economies of scope become more important than economies of scale.

Perhaps the most significant measure of the successful implementation of a Relationship Marketing program is customer value. "If maximizing profit potential is the goal, the critical calculation is the gap between the present and future value of a customer" (Patoka 1999). As already stated, sales and profits per account rise with the length of a relationship. Therefore, everything a firm does for the customer should ensure that revenues increase over time. This is where customer lifetime value comes into play.

The customer lifetime value (LTV) model estimates the profits that a company can expect to receive during the average lifetime of a customer, expressed in today's dollars (Patoka 1999). One way of computing LTV is: Lifetime (in periods) multiplied by average period expenditure. This equation helps to illustrate that the longer an individual stays with a firm, the greater their customer value. More complex models incorporate such other factors as benchmarking data, required rate of return for the firm, gross margin per sale, periodic retention costs, and costs of winning the customer among others (Buttle 1996). 


\section{SAMPLE APPLICATIONS CASE STUDIES}

According to CIO Insight (2006), Back in 1995, Norman Mayne, the CEO of Dorothy Lane Market, knew he was creating a major stir when he was one of the first executives to start talking about "firing" customers. But he did just that, and then launched Club DLM. Still the most radical, data-driven loyalty program in the supermarket industry, Club DLM is aimed squarely at attracting, keeping and pampering only the most profitable and most regular customers at the expense of everyone else. "If you're loyal, we treat you very well," says Mayne, whose father, Calvin, started Dorothy Lane as a roadside food stand in 1948. If you're not, go elsewhere. Mayne fully acknowledges he's ceded the cherry-pickers to Kroger and Meijer, his chain-store rivals. Mayne figures it's one big reason why he's been able to keep Dayton, Ohio-based Dorothy Lane Market in the black amid growing competition.

Along with regular e-mails, the 14,000 members of the loyalty program who receive the newsletter get different versions, depending on their spending levels. Along with food-related tips, the newsletter includes 8 to 12 coupons on the back page. Unlike standard store coupons, however, these coupons are targeted, with different customer groups receiving different batches of coupons and different levels of discounts - depending on what the data tells DLM executives about which customers like what. And the more the customer spends, the better the deal.

Computer companies are also employing successful relationship marketing programs. "The one-to-one approach has worked wonders for Dell, and insiders and outsiders alike attribute its standout performance to a brand of close personal attention that only begins with the design of the product' (Lardner, 1999). Joe Marengi, Senior VP in charge of Dell computer division that serves business customers in the State, said, "Every box we build in this place is built one-to-one. Nothing is built in advance. Nothing is built waiting for an order to come." (Lardner, 1999)

Levi Strauss \& Co., the American jeans company has also hopped on the RM bandwagon. Its customer may order custom-fitted jeans, choosing from three basic models, ten fabrics, five leg styles, and two types of fly (Lardner, 1999). "Retail outlets consist of trained fitters who enter the details on the company's database, and the customer has a barcode in his or her 'perfect' pair of jeans. Reordering a new pair direct from the company thus becomes a simple matter" (Buttle, 1996). Customers are then owners of made-to-fit jeans and the firm experiences reduced inventory costs.

The hospitality sector has also implemented successful one-to-one marketing programs. Ritz-Carlton hotel, for example, has a computer system which houses the desires of half-a-million customers. "The process begins with hotel employees recording insights on...an actual pad of paper. At the end of every day, the facts are keyed into the system. Thereafter, customers never have to ask for the same thing in subsequent visits because whatever they request will be supplied as a matter of course forever after at any Ritz-Carlton" (Lardner, 1999).

Finally, there are firms which are primarily Internet-based such as Amazon.com which "strive to make every customer interaction highly personal, the antithesis of the anonymous strip-mall experience" (Nakache 1998). Once an individual registers on the Web site, they are greeted by name thereafter. The personalized screen shows books, etc., relevant to the individual's previous purchases. The success of a website may be measured by the percentage of browsers who become customers. The average is $2.4 \%$ but Amazon.com's is $5 \%$ (Blake, 1998)

\section{CONCLUSION}

With product quality becoming a standard in many industries, many firms are scrambling to escape the mire of the 'commodity.' Several of these firms are turning to Relationship Marketing as a means of differentiating themselves. This shift to RM is being fueled by fundamental cultural shifts, powerful databases, and new focus of organizational structure and is occurring more rapidly in some sectors and industries than other. Through the relationship they build, marketers turn data into knowledge by using the information, insight, and understanding gained over time and applying this information to mutual benefits with their customers.

As an increasing number of Firms strive to incorporate Relationship Marketing into their operating strategies, marketers must remember that "immediate gratification" is not an attribute of a successful one-to-one marketing. 
They must understand that knowledge is built over the duration of a customer's relationship with a firm. There is no doubt that those firms that take the time to develop a lasting and mutually beneficial relationship with their customers will over the long run dominate those who continue to do business as usual.

\section{REFERENCES}

1. About.COM (2006), Is your Marketing Database Ready for the Primetime? Perry Norgarb

2. $\quad$ Allen, Cliff (1999) One-to One Database Integration. WWW.allen.com

3. Allen, Cliff and Deborah Kania (1999) One-to One Web Marketing WWW.argonvis.com.

4. Beckerman, Robert (1999) Optimize Your Corporate Pillow Talk. WWW. Relationshipmarketing.com.

5. Blake, Paul (1998) Building Relationships with your Web Customers: A new Concept in E-Commerce is IRM. Information Today, Vol.15, issue 9, October.

6. $\quad$ Boone \& Kurtz (1998) Contemporary Marketing Wired, Dryden Press

7. Buttle, Francis (1996) Relationship Marketing: Theory and Practice. London: Paul Chapman Publishing Ltd.

8. Canadian Fundraiser (1997) Harnessing the Power of Database Marketing. May 29

9. CIO Insight (2006) Fire the Worst Customers: Dorothy Lane Market Inc. August 2

10. Dowling, Grahame R. and Mark Uncles (1997) Do Customer Loyalty Programs Really Work? Sloans Management Review June 22.

11. Feldman, Joan M. (1999) Information Technology -Marketing One-to-One-Airlines seek to make Customers feel Special via Automation. Air Transport World, Volume 36, Number 7

12. Kahan, Ron (1998) Using Database Marketing Techniques to Enhance Your One-to-One Marketing Initiatives. The Journal of Consumer Marketing. Vol. 15, No. 5.

13. Kania, Deborah (1999) The Start of a Beautiful Relationship. Precision Marketing by Engage. September 30.

14. Kania, Deborah and Cliff Allen (1999) One to One Web Marketing. Marketing Competence, September 1999

15. Meckback, Greg (1998) Custom Service is Within Reach of Enterprise. Computing Canada, Vol 24, issue 24, June 22.

16. Patoka, Morry (1999) What's the Big Idea in Relationship Marketing? www.relationshipmarketing.com/CRM Info Center.

17. Patoka, Morry (1999) Which Customers to Value Most. www.relationshipmarketing.com/CMR info_center/articles.

18. Patoka, Morry (2000) What's The Big Idea in Relationship Marketing? www.relationshipmarketing.com/CRM Info_Center/Articles/A4/a4.html.

19. Pepper, Don; Martha Rogers and Bob Dorf (1999) Manager's Tool Kit: Is Your Company Ready for One-toOne Marketing? Harvard Business Review. Vol. 77, number 1.

20. Peppers, Don and Martha Rogers (1998) Smart Marketing: Using the Web for One-to-One Marketing. Sales and Marketing Management. Vol. 150, Number 11

21. Peppers, Don and Martha Rogers (1999) Smart Marketing: Implementing an affordable one-to-one marketing program. Sales \& Marketing Management, Vol. 151, no. 5.

22. Phillips, Dave. (1977) Relationship Marketing: Car Companies Bond with Customers to Retain Contact Beyond Showroom. The Detroit News June 22.

23. Vavra, Terry G. (1995) Aftermarketing: How to Keep Customers for Life Through Relationship Marketing. McGraw Hill Companies.

24. White, Sally Button. (1993) Making Your Business Grow: Marketing Strategies that Get Results. Money, October 15.

25. WWW.Lacek.com/relationships/loyalty f.html. (1999) How Can Loyalty Marketing Help My Company.

26. www.relationshipmarketing.com/CRM_Info_Center/Articles (1999) Surveys Foster a Learning Relationship.

27. Zinkewicz, Phil. (1999) Studying the Tactics of a Master Hunter to Compete in the Insurance Jungle: Independent Agents Can Benefit from Direct Writer's Views on Relationship Marketing.

www.roughnotes.com/rnmag/sept/septart4.htm. 